Apidologie, 1988, 19 (2), 117-130

\title{
CONTROL OF VARROA JACOBSONI OUD. IN HONEYBEE COLONIES CONTAINING SEALED BROOD CELLS
}

\author{
N. KOENIGER and S. FUCHS \\ Institut für Bienenkunde (Polytechnische Gesellschaft) \\ Fachbereich Biologie der J.W. Goethe-Universität, Frankfurt/Main \\ Karl-von-Frisch-Weg 2 \\ 637 Oberursel, Fed. Rep. Germany
}

\begin{abstract}
SUMMARY
In traditional chemotherapy, treating colonies during the active season, when considerable parts of the mite population are protected within brood cells, has only limited efficacy. After the treatments, mites emerging from cells with the hatching bees almost immediately replace the losses. One possible way to overcome this difficulty is a continuous treatment releasing constant amounts of acaricide over an extended period. The impact of different treatments on the population dynamics of Varroa jacobsoni is calculated by computer simulations.

Experiments were started recently using carriers impregnated with acaricides (pyrethroids). From these the acaricides are gradually distributed by direct or indirect contact among bees over a period of several weeks. Preliminary experiments demonstrated that colonies can be successfully treated during brood rearing season with this novel method.
\end{abstract}

\section{INTRODUCTION}

The early methods of chemotherapy against varroatosis were mainly general pest control methods. Spraying, dusting, fumigation and aerosol were typical modes of application used in the « first generation » of control methods of Varroa jacobsoni Oud. None of these treatments took into account the biological conditions in the bee colony.

Bees actively clean the hive of all kinds of "pollution " and regulate the interior of the hive to a suitable and nearly constant level of temperature, humidity and $\mathrm{CO}_{2}$. As a result, the introduction of acaricides is almost immediately counteracted by the bees. Therefore the effect of treatments is 
limited to a very short period after their application. Consequently, all mites which are not hit during this short period survive.

To increase the efficacy, treatments are usually repeated several times, which is four times in the application of formic acid (Illertisser Milbenplatte, WACHENDÖRFER et al., 1985) or the fumigation with Folbex (KLEPSCH et al., 1983). This leads to high amounts of the chemicals applied, with the consequence of residue problems in honey and beeswax.

The next step in the improvement of chemical varroa control methods was by feeding acaricides to bees, which are then distributed by natural trophallaxis in the colony. The acaricide then passes into the haemolymph of the bees and kills the mites feeding on them. The first systemic acaricide used for varroa control was Chlordimeform (RuTTNER et al., 1980) which never was officially registered because of residue problems. Later Perizin (Coumaphos) was developed (RITTER, 1985). This is now the most generally used treatment in F.R. Germany. The treatment of colonies is easy and fast : the liquid formulation of Perizin is sprinkled between the combs. A single treatment is efficacious so two replications are sufficient for reaching an efficacy of more than $90 \%$ in broodless colonies.

There is a specific problem with systemic acaricides for varroa control. The bees which take up the administered solution are «loaded» with high amounts of acaricides up to toxicity level. The initial concentration has to be very high because only a limited volume can be applied which, during its passage from bee to bee, is diluted. To reach an acaricide level above varroa toxicity in a maximum number of bees, some initial bee mortality has to be accepted. Systemic acaricides are effective for only a limited period after application (until they are naturally eliminated out of the bee's haemolymph). In this regard they have no advantage compared to previous methods like Folbex, etc. Systemic treatments do not reach mites in capped brood cells.

All the above mentioned methods aim to kill Varroa mites attached to the bees. Reproducing mites are protected within the capped brood cells. Only formic acid is to some degree effective within cells (Adelt and Kimmig, 1986). So most of the traditional acaricides can be applied successfully only during autumn and winter in Central Europe. But using this method, winter bees reared in July and August may already be damaged during their larval and pupal development and the colony may die whether it is treated in autumn or not. The situation is even more critical in Mediterranean countries like Israel, southern France and Spain, where sealed brood is present throughout the year. Apparently, a method is needed which gives successful treatment of colonies containing capped brood cells. 
Quantitative background of chemical varroa control in colonies with capped brood

The efficacy of treatment methods was calculated by computer simulations of the population dynamics of Varroa according to scheme in Fig. 1. The percentage of varroa within brood cells varies to a large extent among colonies ( $5 \%$ to $85 \%$ ) with an average of about $50 \%$ (Fuchs, 1985). To maintain this balance, each day $1 / 12$ of the mites leave the bees and enter worker brood cells, in which they produce an average of 1.4 female offspring (ScHulz, 1984). 12 days later the cells are uncapped. Although $22 \%$ of the mites were

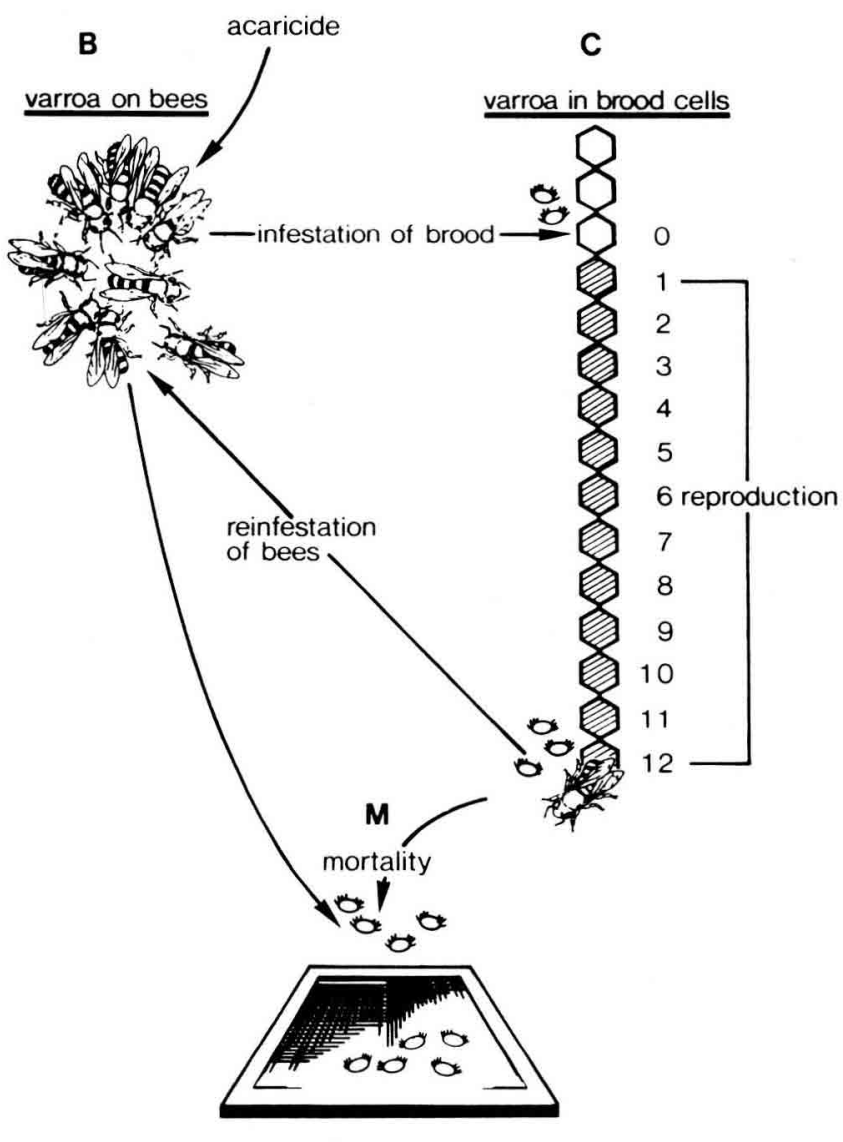

dead mites

FIG. 1. - Scheme of the simplified life cycle of Varroa jacobsoni used for computer simulation of the impact of acaricide treatments on the population growth.

$\mathrm{B}=$ numbers of varroa on bees. $\mathrm{C}=$ numbers of varroa in brood cells. $\mathrm{M}=$ numbers of dead varroa collected on hive bottom inserts. 
found to reproduce a second time in nature (Schulz, 1984), it is assumed for simplicity that after reproduction the old mites die and can be found on the inserts, whereas the young mites reinfest bees. The model calculates on a dayby-day basis the numbers of mites on bees (B), within brood cells (C) and the dead mites on the inserts (M). The population of mites on bees might be depleted by acaricides. These mites are also added to the mites found on the insert.

A conventional treatment in this situation results in a limited short term effect, which at best removes all mites from the bees during 1 day (Fig. 2). After this, mites leave cells, enter bees, re-enter cells and after some regulative fluctuations restore the original population within about 40 days. The effect of a second treatment is demonstrated using a population of constant size $($ reproduction $=$ mortality, Fig. 3). The end level of the curve gives a direct measure of the efficacy of the treatment. It obviously depends on the time interval between the treatments and is highest after 12 days $(82 \%)$, when all surviving mites have left the cells and only a few have re-entered. This

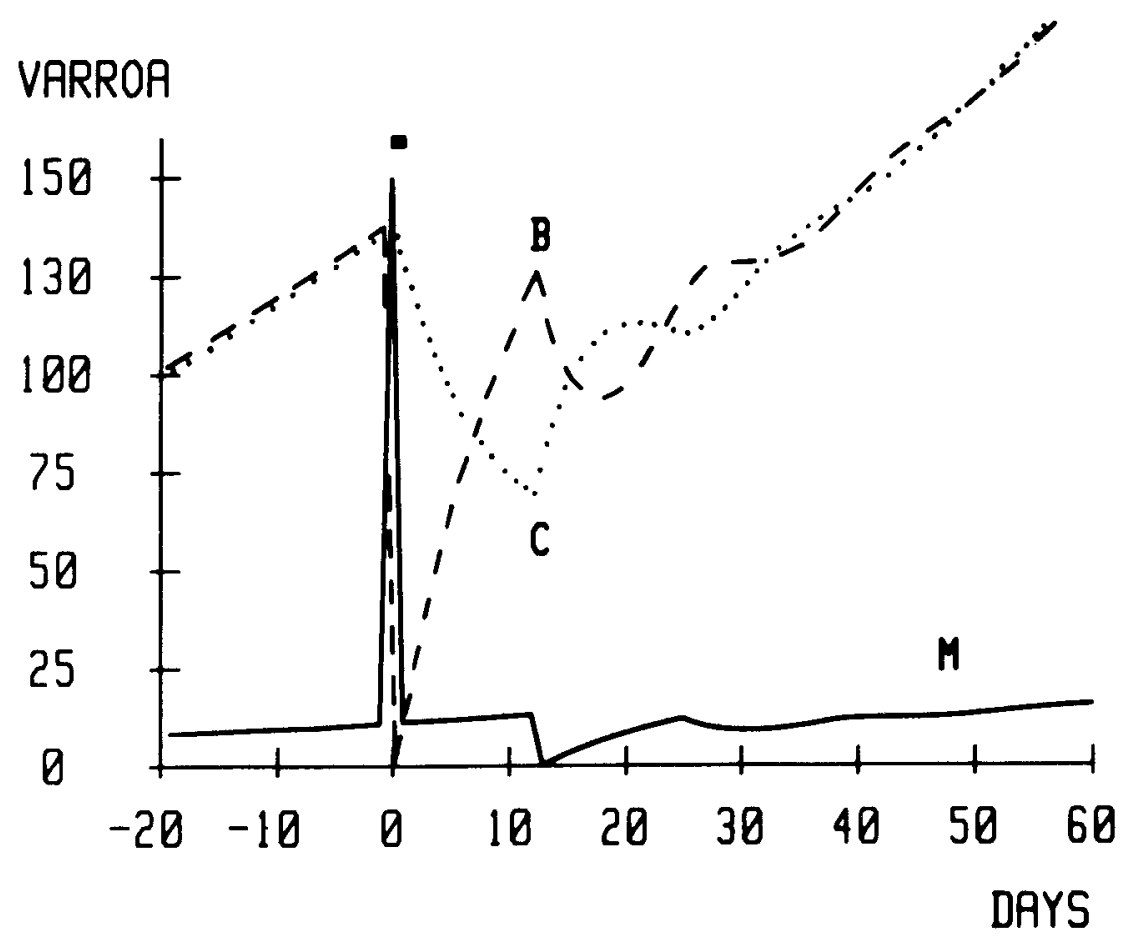

FIG. 2. - Theoretical evaluation of the effect of chemical treatment of one day duration eliminating $100 \%$ of the Varroa on bees in colonies with capped brood.

$\mathrm{B}=$ numbers of varroa on bees. $\mathrm{C}=$ numbers of varroa in brood cells. $\mathrm{M}=$ varroa mortality. 
influence of time interval is less marked in treatments killing less than $100 \%$ of the mites on bees in one day. As a result, these calculations demonstrate that acaricidal effects of short duration, even if repeated, cannot eliminate Varroa or even reduce the population to a tolerable level in colonies containing capped brood cells.

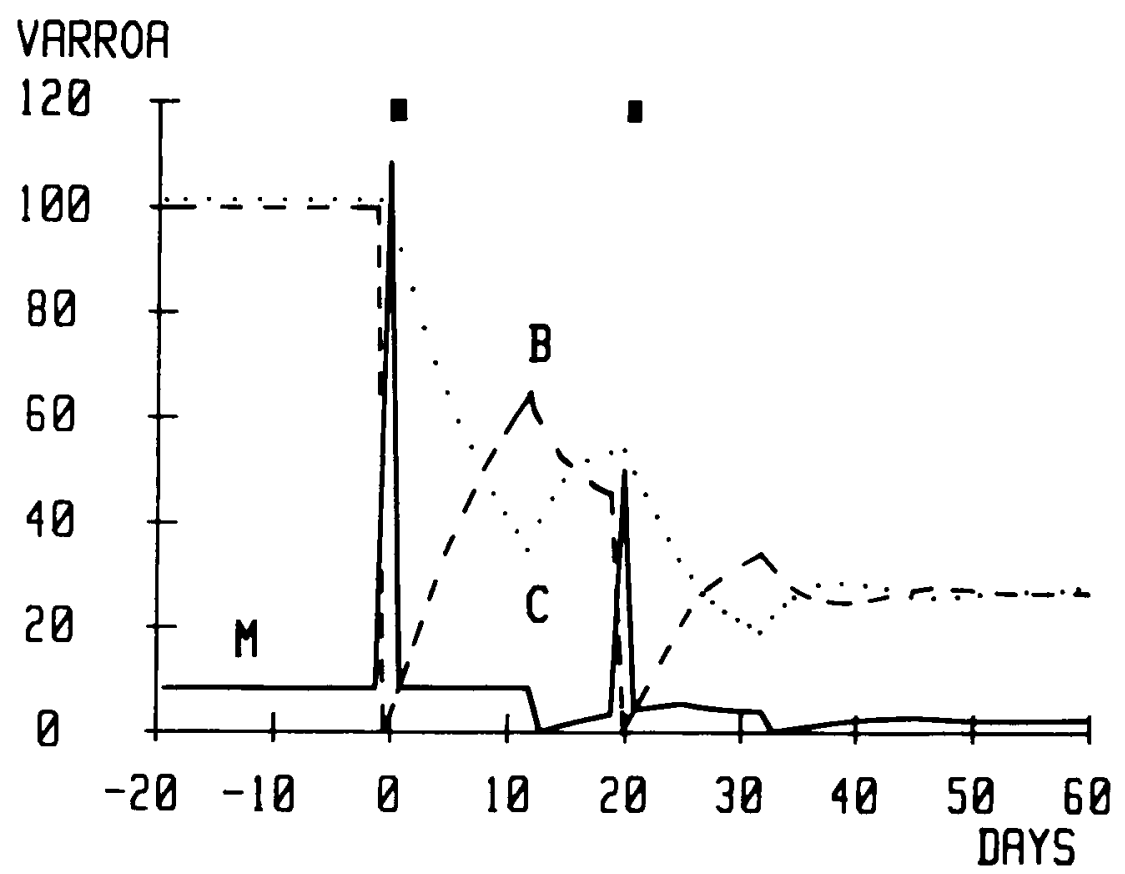

FIG. 3. - Theoretical evaluation of the effect of two chemical treatments of one day duration each eliminating $100 \%$ of the Varroa on bees in colonies with capped brood.

$\mathbf{B}=$ numbers of varroa on bees. $\mathrm{C}=$ numbers of varroa in brood cells. $\mathbf{M}=$ varroa mortality.

In contrast, simulations of an alternative approach give more satisfactory results. Continuous treatments over extended periods of some weeks remove mites as they emerge from brood cells. In case of $100 \%$ efficacy (removal of all Varroa on bees within $24 \mathrm{~h}$ ) the treated colony will be cured after the period of cell capping lasting 12 days. By then the last mites have emerged from cells, but no cells have been reinfested. With a more realistic assumption of a constant efficacy of $50 \%$ per day the colony will be cured within a month (Fig. 4). The numbers of dead mites per day give a characteristic pattern with a marked peak during the first few days, when the Varroa population on bees is drastically reduced. During the following 12 days, a constant level of killed mites mainly consists of those emerging from cells. At the same time, some reinfestation of brood cells occurs which leads to a second plateau of mites emerging from cells and being killed. After 30 days, only very few mites $(0.1 \%)$ survive. 


\section{VARROA}

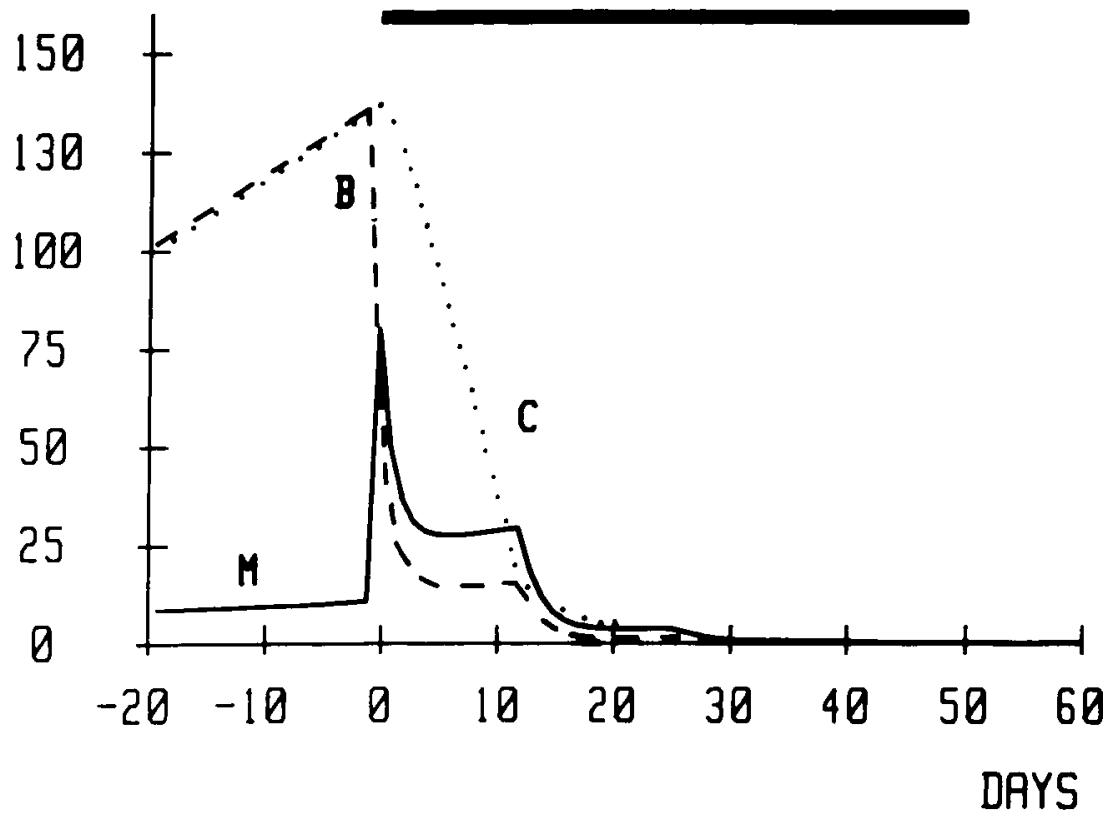

Fig. 4. - Theoretical evaluation of the effect of a continuous chemical treatment of 50 days duration each day eliminating $50 \%$ of the varroa on bees in colonies with capped brood. $\mathrm{B}=$ numbers of varroa on bees. $\mathrm{C}=$ numbers of varroa in brood cells. $\mathrm{M}=$ varroa mortality.

\section{Carriers}

We tried to achieve a constant release of acaricides by using impregnated carriers which were introduced into the hive. In bioassay tests carried out within cages containing 10 infested bees, pyrethroids proved to be very effective over sufficiently long periods of time. The pyrethroids used were Bayvarol (Bayer A.G.) and Fluvalinate (Zoecon Corp.). Both substances showed a high varroacidal activity combined with a low bee toxicity. The principle of dispersal of the acaricide within the colony is by contact from the carrier to the bee and then from bee to bee and on the varroa mites on them. This pathway was demonstrated by cage tests (Koeniger, 1986). The first experiments were conducted using plywood carriers. Later several synthetic materials such as polyester, pvc, polyurethane, polyethylene and polystyrol were tested. The structure of the carrier and chemical nature of the acaricide both strongly influence the effect of the release and must be very well adjusted. 


\section{Application of acaricide carriers within hives}

\section{METHODS}

To determine an effective position in which carriers can be placed within colonies, the following variations were examined within broodless colonies $\left(0.5 \mu \mathrm{g} / \mathrm{cm}^{2}\right.$ Bayvarol, 2 colonies/variation) :

1. An impregnated inner cover was placed above the combs.

2. Two impregnated partitions were placed in bee spaces between the combs.

3. An impregnated plywood grid (Bausperre) was placed under the combs.

The treatments lasted 27 days. The numbers of surviving mites were determined by washing the mites from the bees with detergent water (FucHs, 1986).

Experiments with colonies containing brood were carried out with comb partitions (surface area $760 \mathrm{~cm}^{2}$ ). In experiment 1 , one partition was inserted in the middle of the colony ( 5 colonies, duration of treatment 60 days), in experiment 2 , two partitions were placed 3 bee spaces apart ( 20 colonies, duration of treatment 70 days). The numbers of dead mites on the inserts was registrated daily during the first 18 days and in 7 day intervals thereafter.

As a commercialized product available to the bcekeeper, pyrethroids will be incorporated into plastic carriers. One of these products was tested during a period of 53 days in 30 colonies containing brood combs starting at mid-july.

\section{RESULTS}

The efficacies of carriers in different hive positions is given in Table 1. The best results were obtained with comb partitions, which eliminated about $99 \%$ of varroa mites within 27 days, whereas grids or covers were clearly much less effective.

TABL. 1. - Efficacy of plywood carriers impregnated with pyrethroid $\left(0.5 \mu \mathrm{g} / \mathrm{cm}^{2}\right.$ BAYVAROL) at different hive positions (inner cover above combs, comb partitions, grid below combs) within broodless colonies during 27 days.

\section{Cover :}

Colony 1

Colony 2

Grid :

Colony 1

Colony 2

Partition :

Colony 1

Colony 2

\begin{tabular}{|c|c|c}
\hline Total varroa & Surviving varroa & Efficacy (\%) \\
\hline & & \\
584 & 32 & 94.5 \\
1949 & 366 & 81.2 \\
& & \\
1626 & 179 & 89.9 \\
1948 & 518 & 73.4 \\
2205 & 3 & 99.9 \\
441 & 6 & 98.6 \\
\hline
\end{tabular}


TABL. 2. - Efficacy of treatments with BAYVAROL impregnated plywood carriers $\left(0.5 \mu \mathrm{g} / \mathrm{cm}^{2}\right)$ in colonies containing brood. Experiment $I: 1$ comb partition, treatment duration $60 \mathrm{~d}$.

Experiment $2: 2$ comb partitions, treatment duration $70 \mathrm{~d}$

\begin{tabular}{l|c|c|c|c}
\hline \hline & Colony & Total varroa & Surviving varroa & Efficacy (\%) \\
\cline { 2 - 5 } Experiment $1:$ & 1 & 2313 & 11 & 99.5 \\
& 2 & 1722 & 10 & 99.4 \\
& 3 & 1392 & 264 & 81.0 \\
& 4 & 3884 & 3 & 99.9 \\
\hline Mean & 5 & 2840 & 37 & 98.7 \\
\hline Experiment 2: & & 2430 & 65 & 95.7 \\
& 1 & 1395 & 18 & 98.7 \\
& 2 & 686 & 28 & 95.9 \\
& 3 & 4457 & 14 & 99.7 \\
& 4 & 3039 & 577 & 81.0 \\
& 5 & 722 & 15 & 97.9 \\
& 6 & 798 & 106 & 86.7 \\
& 7 & 4618 & 2 & 100.0 \\
& 8 & 507 & 6 & 98.8 \\
& 9 & 999 & 4 & 99.6 \\
& 10 & 2145 & 476 & 77.8 \\
& 11 & 768 & 20 & 97.4 \\
& 12 & 834 & 6 & 99.3 \\
& 13 & 738 & 22 & 97.0 \\
& 14 & 3312 & 84 & 96.7 \\
& 15 & 1142 & 38 & 96.7 \\
& 16 & 619 & 7 & 98.9 \\
& 17 & 1001 & 24 & 97.6 \\
& 18 & 1315 & 62 & 95.3 \\
& 19 & 1965 & 18 & 97.4 \\
& 20 & 1643 & 79 & 95.6 \\
\hline
\end{tabular}

During treatments with wooden carriers in colonies containing brood, the total efficacy was about $95 \%$ in both experiments (Table 2). The mean percentages of the total numbers of mites in the colonies killed each day is shown in Fig. 5. High numbers of mites were killed each day, while approximatively constant numbers were registered during the 12 following days with a subsequent drop to much lower numbers thereafter. This closely reflects the pattern of the theoretical evaluation (c.f. Fig. 4). In tests using plastic carriers, during 53 days about $99 \%$ of varroa could be eliminated from colonies containing brood (Table 3 ). In 20 out of 30 colonies (67\%), efficacies were more than $99 \%$. In only one colony, it was less than $95 \%$.

FIG. 5. - Field experiment on the efficacy of a continuous treatment with carriers (plywood comb partitions, $0.5 \mu \mathrm{g} / \mathrm{cm}^{2}$ Bayvarol) in colonies containing capped brood cells.

Ordinate : \% dead varroa/day. Abscissa : duration of treatment.

Above : means of 5 colonies. Value of the first day : $51.1 \%$.

Below : means of 20 colonies. Value of the first day : $41.1 \%$. 


\section{MORT./DAY (\%)}

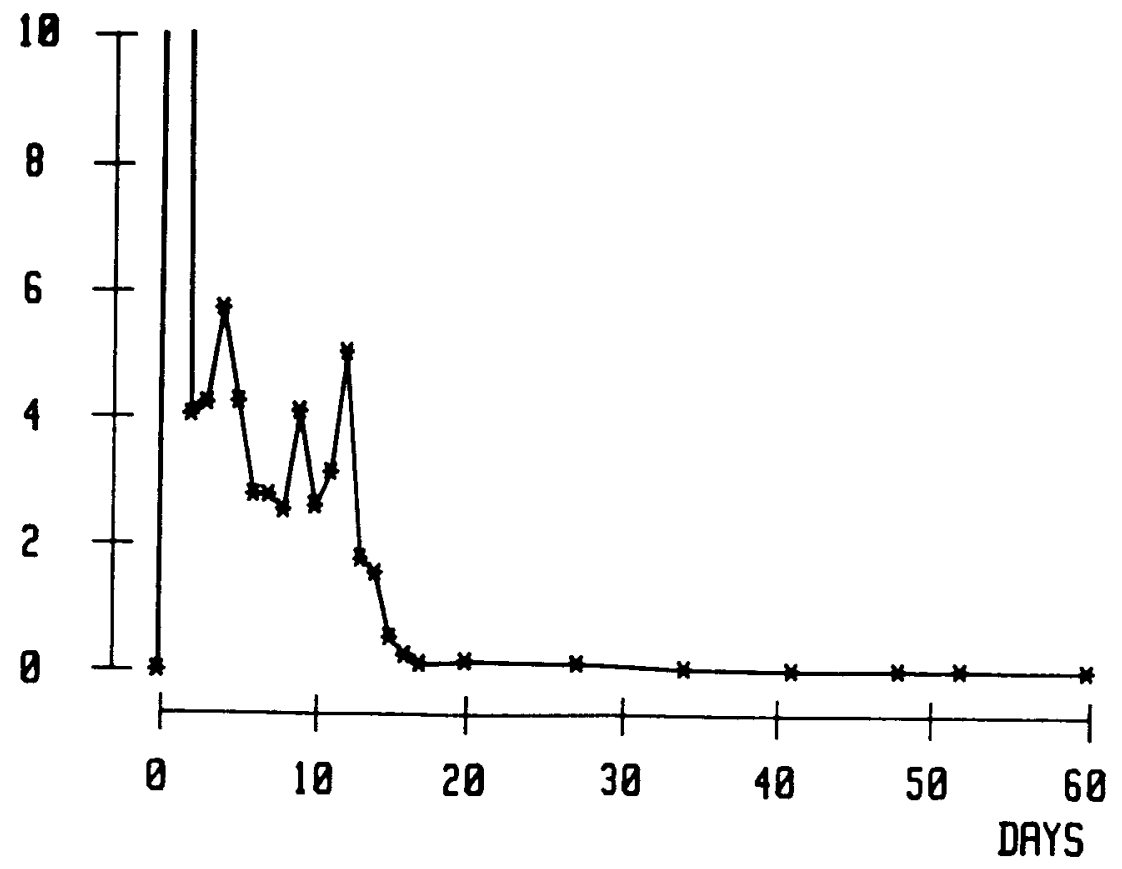

MORT. /DAY (\%)

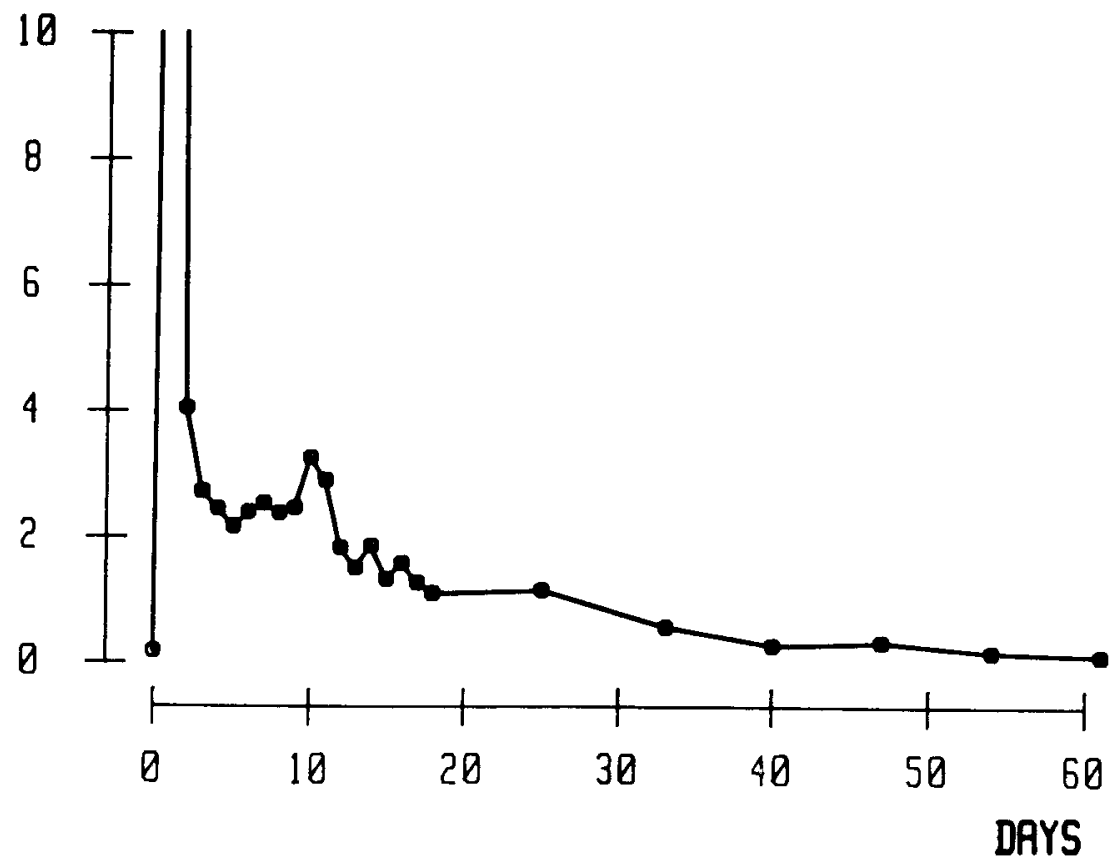


TABL. 3. - Efficacy of treatments with pyrethroids in plastic strips.

Strips in bee spaces of colonies with brood. Duration : 53 days.

\begin{tabular}{|c|c|c|c|}
\hline Colony & Total varroa & Surviving varroa & Efficacy $(\%)$ \\
\hline $\begin{array}{l}1 \\
2\end{array}$ & $\begin{array}{l}594 \\
786\end{array}$ & $\begin{array}{l}1 \\
4\end{array}$ & $\begin{array}{l}99.8 \\
99.5\end{array}$ \\
\hline 3 & 656 & 6 & 99.1 \\
\hline 4 & 338 & 1 & 99.7 \\
\hline 5 & 473 & 0 & 100 \\
\hline 6 & 662 & 1 & 99.8 \\
\hline 7 & 682 & 7 & 99.0 \\
\hline 8 & 56 & 2 & 96.4 \\
\hline 9 & 48 & 1 & 97.9 \\
\hline 10 & 221 & 1 & 99.5 \\
\hline 11 & 197 & 0 & 100 \\
\hline 12 & 661 & 3 & 99.5 \\
\hline 13 & 213 & 20 & 90.6 \\
\hline 14 & 267 & 6 & 97.8 \\
\hline 15 & 599 & 0 & 100 \\
\hline 16 & 357 & 1 & 99.7 \\
\hline 17 & 672 & 6 & 99.1 \\
\hline 18 & 79 & 1 & 98.7 \\
\hline 19 & 801 & 17 & 97.9 \\
\hline 20 & 386 & 10 & 97.4 \\
\hline 21 & 695 & 9 & 98.7 \\
\hline 22 & 437 & 10 & 97.7 \\
\hline 23 & 705 & 2 & 99.7 \\
\hline 24 & 977 & 4 & 99.6 \\
\hline 25 & 516 & 1 & 99.8 \\
\hline 26 & 425 & 0 & 100 \\
\hline 27 & 2486 & 0 & 100 \\
\hline 28 & 646 & 2 & 99.7 \\
\hline 29 & 4295 & 1 & 100 \\
\hline 30 & 6736 & 2 & 100 \\
\hline Mean & 889 & 4 & 98.9 \\
\hline
\end{tabular}

\section{DISCUSSION}

It is obvious that a considerable improvement has been achieved in chemotherapy during the past few years. Beekeepers in most parts of Europe are now in a position to avoid damage by Varroa. On a regular basis all colonies have to be monitored and treated twice or at least once a year. Therefore, chemical varroa control is now a regular routine in beekeeping. It 
is a significant factor in the economics of honey production, because considerable labor and costs are involved.

Further progress will result from the current research. The introduction of constant release carrier methods will for the first time allow an effective treatment of colonies with capped brood. This is of crucial importance if the severe problems of varroa control in the southern regions of Europe are to be solved. The method involves low labor costs and minimizes the risk of misdosing. By using the natural pathway of distribution by contact from bee to bee, it is hoped that residues can be kept low. Preliminary analyses are encouraging in this respect. After the treatment, the acaricide not used is removed with the carrier. This reduces the likelihood of sublethal concentrations remaining in the colony which might promote the development of resistance. The development of the carrier method has not yet been completed, but we hope that the remaining problems can be overcome and the carrier method will get official registration soon.

The eradication of varroatosis in Europe seems not to be a realistic goal. For the next decades, beekeeping will depend on solutions of the varroa control problems. In this regard, chemotherapy involves considerable disadvantages and risks. It is known that resistance of mites to chemical control agents occurs frequently. There are already some indications that this happens in Varroa jacobsoni to some chemicals. Further, in long term chemical varroa control, residues may accumulate in honey as well as in beeswax. Thus, the development of control methods apart from the use of chemicals will have a high priority in future. However, most research projects on biotechnical or genetic solutions are in a very early stage and the outcome is still uncertain.

Received for publication in September 1987. Accepted for publication in November 1987.

\section{ACKNOWLEDGEMENTS}

With financial support from the European Community, Bayer and Zoecon. We want to thank Dr. M. Chmielewski, R. Rafiroiv, M. Ullman, B. Berg and many others. Without their contributions and ideas the results presented would not have been possible. 


\section{RÉSUMÉ \\ MÉTHODE DE LUTTE CONTRE VARROA JACOBSONI OUD. DANS DES COLONIES D'ABEILLES RENFERMANT DU COUVAIN OPERCULE}

Dans les méthodes habituelles de traitement, la durée d'action de l'acaricide dans la ruche est très courte. Tous les acariens qui passent cette période sans dommage se reproduisent et rendent nécessaire la répétition du traitement peu de temps après. Les méthodes actuelles présentent une autre restriction importante: les acariens présents dans les cellules de couvain operculé ne sont pas atteints par l'acaricide.

On a évalué l'efficacité de diverses variantes du traitement par un calcul de simulation. La proportion de varroas sur les abeilles et dans les cellules de couvain varie de 5 à $85 \%$ avec une valeur moyenne de $50 \%$, que l'on a retenue pour le modèle présenté ici ; puis on a introduit dans les calculs les taux de reproduction de Varroa jacobsoni indiqués par Schulz (1984). Un traitement traditionnel ne produit qu'un effet limité dans les temps (Fig. 2). Afin de montrer l'action de la répétition d'un traitement, on a considéré dans le modèle une population constante de varroas (Fig. 3). L'intervalle entre 2 traitements a une influence sur le degré d'efficacité. Ces calculs de modélisation montrent que, même avec des applications répétées, des traitements avec des acaricides à durée d'action courte sont inappropriés pour des colonies possédant du couvain operculé. Par contre des méthodes qui agissent plus longtemps atteignent également les acariens qui sont sortis du convain operculé. Les colonies traitées sont guéries à $100 \%$ au bout de 12 jours. Si l'on prend comme hypothèse réaliste, une efficacité de $50 \%$ par jour, une colonie sera exempte d'acariens après un traitement de 30 jours (Fig. 4).

Pour tester pratiquement cette évaluation, on a appliqué sur des supports en contreplaqué les acaricides pyréthrinoïdes suivants : Bayvarol ${ }^{R}$ (Bayer S.A.) et Fluvalinate ${ }^{R}$ (Zoecon Corp.). On a noté une efficacité de $99 \%$ suite à l'introduction des supports entre les cadres (Fig. 5). Lors d'un essai en champ sur des colonies qui renfermaient de grandes quantités de couvain operculé, on a atteint une efficacité supérieure à $99 \%$ au cours d'un traitement de 50 jours (Fig. 6).

L'introduction de supports acaricides en matériaux synthétiques à durée d'action longue et constante va rendre possible le traitement de la varroatose pendant la période de production de couvain. On dispose ainsi d'un traitement efficace en été après la miellée, avant la production des abeilles d'hiver. Les énormes difficultés rencontrées actuellement en Europe méridionale dans la lutte contre Varroa seront ainsi amoindries.

\section{ZUSAMMENFASSUNG}

\section{VARROATOSE-BEHANDLUNG VON BIENENVÖLKERN MIT VERDECKELTEN BRUTZELLEN}

Bei den üblichen Behandlungsmethoden ist die Zeit der Wirksamkeit der Akarizide im Bienenvolk nur sehr kurz. Alle Milben welche diese Periode überlebt haben, vermehren sich weiter und machen nach kurzer Zcit eine Wiederholung der Behandlung erforderlich. Eine wichtige weitere Einschränkung der bisherigen Methoden besteht darin, daß die Milben, die sich in der verdeckelten Brut befinden, von den Akariziden nicht erfasst werden.

Die Effektivität verschiedener Behandlungsvarianten werden durch eine Simulationsrechnung abgeschätzt. Das Verhältnis von Varroa auf den Bienen und in den Brutzellen ist variabel und schwankt zwischen $5 \%$ und $85 \%$. In dem hier vorgestellen Modell wird eine konstante Brutmilbenproportion von $50 \%$ unterstellt. Weiter haben wir die Varroa-Reproduktionswerte von Schulz (1984) für die Kalkulationen eingesctzt. Eine konventionelle Behandlung ergibt nur einen zeitlich begrenzten Effekt (Fig. 2). Um die Wirkung einer wiederholten Behandlung zu zeigen, haben wir eine konstante Milbenpopulation im 
Modell vorgegeben (Fig. 3). Der Abstand zwischen zwei Behandlungen hat einen Einfluß auf den Wirkungsgrad. Diese Modellrechnungen zeigen, daß auch bei wiederholten Applikationen Behandlungen mit kurz wirkenden Akariziden für Völker mit verdeckelter Brut nur beschränkt wirksam sind. Dagegen erfassen langandauernd wirksame Methoden auch die Milben, die aus der verdeckelten Brut freigesetzt werden. Mit einer $100 \%$ igen Wirksamkeit sind nach 12 Tagen behandelte Völker geheilt. Bei einer realistischeren Annahme von einer Wirksamkeit von $50 \%$ pro Tag wird ein Volk nach 30-tägiger Behandlungsdauer ohne Milben sein (Fig. 4).

Für eine praktische Verwirklichung dieses Ansatzes wurden Akarizide (Pyrethroide : Bayvarol (Fa. Bayer), Fluvalinat (Coecon Corp.) auf Trägern (Sperrholz) eingesetzt. Bei Einbringung von Trägern in die Wabengassen ergab sich eine Wirksamkeit von $99 \%$ (Fig. 5). In einem Feldversuch mit Völkern, die große Mengen von verdeckelter Brut enthielten, wurde während einer 50-tägigen Behandlungszeit ein Effekt von mehr als $99 \%$ erreicht (Fig. 6).

Die Einführung von weiterentwickelten Trägern aus synthetischen Materialien mit konstanter, langzeitiger Wirkungsdauer wird die Behandlung der Varroatose während der Brutperiode der Bienenvölker ermöglichen. Damit könnte eine wirksame Behandlung im Sommer nach der Tracht, also vor Erzeugung der Winterbienen möglich werden. Die zur Zeit bestehenden erheblichen Schwierigkeiten bei der Varroatosc-Bchandlung im südlichen Europa könnten gemildert werden.

\section{LITERATUR}

Aрelt В., Кіммісн X.H., 1986. - Dic Wirkung der Ameisensäure in die verdeckelte Brut. Allgemeine Deutsche Imkerzeitung, 20 (12), 382-386.

Fuchs S., 1986. - Untersuchungen zur quantitativen Abschätzung des Befalls von Bienenvölkern mit Varroa jacobsoni Oudemans und zur Verteilung des Parasiten im Bienenvolk. Apidologie, 16 (4), 343-368.

Klepsch A., Maul V., Petersen N., Koeniger N., Götz W., 1983. - Feldversuch zur Varroatosebekämpfung mit Folbex Va Ncu. Die Biene, 119 (2), 54-57.

Kofniger N., 1986. - Dispersal of acaricides in bee colonies by means of natural contact among the bees. Apidologie, 17 (4), 381-383.

Ritrer W., 1985. - Bekämpfung der Varroatose mit Perizin, einem neuen systemischen Medikament. Apidologie, 16 (3), 219-220.

Ruttner F., Ritter W., Götz W., 1980. - Chemotherapie der Varroatose über die Haemolymphe der Bienc. Allgemeine Deutsche Imkerzeitung, 14 (5), 160-165.

Schulz A., 1984. - Reproduktion und Populationsentwicklung der parasitischen Milbe Varroa jacobsoni in Abhängigkeit vom Brutzyklus ihres Wirtes Apis mellifera. Apidologie, 15 (4), 401-420.

Wachendörfer G., Fijalkowski J., Kaiser E., Seinsche D., Siebentritt J., 1985. — Labor- und Feldversuche mit der Illertisser Milbenplatte als neue Anwendungsform der Ameisensäure im Rahmen der Varroatose-Bekämpfung. Apidologie, 16 (3), 291-306. 